\title{
Ressecção lateral do canal auditivo em três equinos
}

Kamila Pinheiro Paim, Raíssa Oliveira Leite, Eriky Akio Tongu, Bruna Souza Teixeira, Layane Queiroz Magalhães, Tatiane Faria Prado, João Paulo Elsen Saut, Diego Jose Zanzarini Delfiol, Geison Morel Nogueira”

Universidade Federal de Uberlândia (UFU), Uberlândia, MG, Brasil

*Autor correspondente

e-mail: geison.nogueira@ufu.br

\section{Resumo}

A otite externa é uma enfermidade inflamatória e/ou infecciosa do canal auditivo e pavilhão auricular externo. As principais causas são aumento de umidade e presença de ectoparasitas associada a infecções bacterianas secundárias. Casos crônicos e recorrentes de otite externa podem levar à estenose do canal auditivo, otite média e a quadros de síndrome vestibular. São sinais clínicos frequentes a presença de secreção purulenta e sensibilidade dolorosa na região do conduto auditivo. 0 diagnóstico se baseia no histórico, sinais clínicos e exames complementares, como a cultura e isolamento do agente, exame radiográfico e endoscopia de bolsa gutural. Como tratamento clínico deve-se instituir a antibioticoterapia e limpeza do conduto auditivo. Contudo, em casos onde há estenose do canal, deve-se associar a terapia cirúrgica para que seja possível a drenagem do conteúdo purulento e acesso ao mesmo. Relata-se três casos de otite externa em equinos, machos, sem raça definida, submetidos à técnica operatória de ressecção lateral do canal auditivo. 0 primeiro equino, com 20 anos de idade, apresentava sensibilidade dolorosa, estenose completa na abertura do conduto auditivo esquerdo e presença de secreção purulenta no direito. 0 segundo, com 4 anos de idade, apresentava presença de secreção purulenta fétida e redução da abertura do canal auditivo esquerdo. 0 terceiro, com 16 anos, apresentava sensibilidade dolorosa, estenose completa do conduto auditivo esquerdo e presença de fístula próxima ao mesmo. Foi instituída antibioticoterapia com ceftiofur sódico para os três animais, na dose de 4,4 mg/Kg, via intravenosa, uma vez ao dia, durante 10 dias, além de terapia anti-inflamatória com meloxican, $2,2 \mathrm{mg} / \mathrm{kg}$, via intravenosa, duas vezes ao dia, durante 5 dias, omeprazol, 4,0 mg/Kg, via oral, uma vez ao dia, pelo mesmo período, e limpeza do conduto auditivo com solução à base de propilenoglicol e clorexidine 0,5 \%. Os equinos foram submetidos a protocolo de anestesia geral inalatória para realização da técnica de ressecção lateral do canal auditivo. Após tricotomia e antissepsia da região do conduto, foi procedida uma incisão de pele, em forma de "U”, sobre a porção vertical do canal, tendo início e término na fenda intertragal 
e estendendo-se até $1,0 \mathrm{~cm}$ ventralmente à base cartilaginosa palpável do conduto. Divulsionados a pele e subcutâneo, visualizou-se a parede lateral do canal auditivo, sendo possível a realização de duas incisões paralelas, desde a fenda intertragal até a base do conduto. Excisado o retalho cartilaginoso da parede lateral, procedeu-se a sutura do epitélio do canal auditivo à pele com fio de náilon 0 , utilizando padrão de sutura contínua. Os condutos foram submetidos à lavagem com solução fisiológica no transoperatório. Houve a recuperação completa dos casos em média de duas semanas após o procedimento. A técnica de ressecção lateral do conduto auditivo foi importante para o tratamento da otite externa nestes animais, permitindo o acesso ao canal para limpeza e drenagem do conteúdo, e auxiliando na recuperação dos animais.

Palavras-chave: Otite. Estenose. Ectoparasitas. 